Al-Manhaj: Journal of Indonesian Islamic Family Law, 3 (1), 2021: 1-21

ISSN: 2715-003; E-ISSN 2714-5514

DOI: http://dx.doi.org/10.19105/al-manhaj.v3i1.3741

\title{
Administrasi Perkawinan Dalam Mencegah Pernikahan Dini di Kecamatan Pakong Kabupaten Pamekasan \\ Madura
}

\author{
Imam Hanafi \\ (Institut Agama Islam Negeri (IAIN) Madura, email: rafirama140117@gmail.com)
}

\begin{abstract}
Abstrak:
Di dalam komunitas masyarakat muslim bangsa Indonesia, pernikahan dapat juga di lihat sebagai wujud penyatuan dua kumpulan ikatan keluarga besar. Persatuan yang dimaksud adalah menyatunya kedua keluarga tersebut hidup damai dan bahagia dengan menjadikan seseorang mempunyai pasangan istri, dan demikian juga seorang istri mempunyai pasangan suami. (In the Indonesian Muslim community, marriage can also see $n$ as a form of the union of two large family ties. The unity in question is the uniting of the two families to live in peace and happiness by making a person have a wife partner, and likewise, a wife has a husband partner.)
\end{abstract}

Kata Kunci:

Pernikahan, Keluarga

\section{Pendahuluan}

Pernikahan pada hakikatnya adalah untuk menciptakan suasana bahagia, baik bagi kedua pasangan suami istri, maupun untuk dua keluarga dari pasangan tersebut, dan sekaligus kepada seluruh ummat manusia. Tujuan tersebut sesuai dengan fitrah manusia dan senafas dengan tujuan hukum Islam sebagaimana yang disebut oleh para pakar filsafat hukum Islam dengan istilah "alTahshil wa al-Ibqa'" yaitu untuk mencapai kebahagiaan hidup dan mempertahankannya.

Pada aspek sosiologi (ilmu masyarakat), seperti kenyataan di dalam masyarakat muslim bangsa Indonesia, per-nikahan dapat 
dilihat sebagai kejadian penyatuan dua kelompok kalangan keluarga besar. Bahkan, perkawinan menjadikan sarana terbentuknya satu keluarga besar yang asal mulanya terdiri dari dua keluarga dan tidak saling mengenal baik, antara keluarga suami dan keluarga istri, kemudian mereka saling memahami serta membentuk suatu ikatan keluarga, atau yang semula hanya perpaduan dua insan, akhirnya dapat menjadi sarana pemersatu dua keluarga menjadi satu-kesatuan utuh dan menyatu. Persatuan yang dimaksud adalah menyatunya kedua keluarga tersebut hidup damai dan bahagia.

Institusi perkawinan merupakan salah satu inti pertahanan dari segala macam penghancuran eksistensi kehidupan, baik agama, kehormatan, jiwa dan kelangsungan generasi. Oleh karena itu, pasangan suami istri di tuntut untuk mampu menjaga, merawat, membimbing, mendidik, membina, menjamin dan mempertahankan kehidupan rumah tangganya tersebut dari segala ancaman yang akan menghancurkannya. Untuk menuju kebahagiaan hidup berumah tangga, tidak hanya bergantung kepada terpenuhinya kebutuhan materi secara memadai, tetapi yang paling penting adalah bagaimana mereka memahami, mendalami dan menghayati tentang nilai-nilai berumah tangga, khususnya bagi diri seorang calon mempelai sebelum mereka memasuki jenjang pernikahan.

Di dalam Islam hukum dan aturan tersebut telah disebut dengan jelas tujuan dari perkawinan itu, yakni untuk memelihara kemaslahatan manusia, sekaligus untuk menghindari mafsadat baik di dunia maupun akhirat. Kemaslahatan inilah yang harus diupayakan secara maksimal. Apabila suatu perkawinan diarahkan untuk mewujudkan kemaslahatan, maka diperlukan sikap dan tanggung jawab untuk menghadapi bermacam rupa tantangan dan mengatasi bermacam ragam persoalan hidup. Kemudian si mempelai harus tahu batasan antara kewajiban individu dan responsibilitas bersama, kemudian bagaimana pula cara melaksanakannya.

Sebagaimana lazimnya, pernikahan yang dilangsungkan di dalam komunitas masyarakat muslim dicatat oleh Pegawai Pencatat Nikah di Kantor Urusan Agama (KUA) domisili setempat. Hal ini sesuai dan sinkron dengan pasal 2 ayat (1) PP No. 9 tahun 1975. Selanjutnya, pasal 6 ayat (1) menyebutkan bahwa, "Pegawai Pencatat Nikah yang menerima pernyataan pemberitahuan keinginan melangsung kan perkawinan dari individu dan masyarakat, 
kemudian memeriksa, menyelidiki dan meng investigasi apakah syarat-syarat pernikahan tersebut telah dipenuhi, sehingga tidak lagi terdapat halangan perkawinan menurut Undang-Undang (UU)" .

Undang-Undang dan peraturan perkawinan yang dijalankan oleh PPN dan pembantu PPN adalah sebagai salah satu pintu bagi terwujudnya kemaslahatan perkawinan. Oleh karena itu, masyarakat perlu didorong kesadarannya agar mengetahui perlunya persiapan pendahuluan sebelum melangsungkan hajad tersebut. Adapun persiapan pendahuluan itu adalah menyangkut hal-hal sebagai berikut.

Pertama, Masing-masing calon pengantin saling melakukan kesepakatan apakah mereka setuju, dan kedua orang tua merestuinya; Kedua, Masing-masing ahli famili calon pengantin berusaha memeriksa, mempelajari dan menggali apakah ada halangan perkawinan, baik menurut hukum munakahat maupun menurut per UU yang berlaku;

Ketiga, Hendaknya calon pengantin terlebih dahulu mempelajari dan mengkaji pengetahuan tentang kerumah-tanggaan, hak dan kewajiban suami, maupun istri dan lain sebagainya; dan Keempat, Calon pengantin memeriksakan kesehatannya guna terjaminnya tingkat kualitas keturunan. Setelah persiapan pendahuluan pernikahan dilakukan secara matang, selanjut nya orang yang hendak melangsungkan pernikahan tersebut memberitahukan keinginannya kepada PPN/Pembantu setempat, sekurang-kurangnya sepuluh (10 hari) sebelum kesepakatan akad nikah dilangsungkan.

Penelitian ini menggunakan pendekatan kualitatif, dengan metode pengumpulan data melalui observasi, wawancara dan dokumentasi. Ada pun lokasi penelitiannya yaitu di Kecamatan Pakong Kabupaten Pamekasan Madura. Dengan melibatkan masyarakat yang berkaitan dan pegawai Kantor Urusan Agama (KUA) Kecamatan Pakong Kabupaten Pamekasan.

\section{Ketentuan Administrasi Pernikahan dalam Perspektif Nash Pandangan Ulama'}

Para ulama' salaf telah merumuskan suatu syarat atau rukun perkawinan dalam bentuk hasil pemikiran atau ijtihad. Kebutuhan manusia terhadap rumusan rukun dan syarat menjadi hal yang 
penting dalam rangka menjembatani antara apa yang dijelaskan dalam nash baik al-Qur'an maupun hadist Nabi Muhammad S AW. yang ber- sifat prinsip, hal itu sangat urgen dilakukan agar dapat dipraktikkan dalam kehidupan riil/nyata. Nash -nash dalam alQuran maupun hadist Nabi Muhammad SAW yang berisi aturan dalam bidang perkawinan sebagaimana juga nash muamalah lainnya, secara umum dapat diklasifikasikan kepada dua kelompok besar, yaitu; pertama, nash normatif sistematis universal dan yang kedua adalah nash praktis temporal.

Nash al-Quran sebagai petunjuk (hudan) atau acuan moral dan etik yang bersifat prinsip dan atau dasar yang sempurna serta dapat menjawab semua persoalan dinamis seperti apapun komplikasi masalah yang timbul dari kurun waktu ke periode waktu berikutnya. Dengan ungkapan lain, sedinamis apa pun persoalan yang muncul sudah ada jawabannya yang bersifat prinsip dalam al-Qur'an. Adapun usaha menjembatani dari petunjuk yang bersifat moral dan etik yang bersifat prinsip menjadi aturan praktis dan untuk menjawab persoalan secara teknis operasional dibutuhkan ijtihad. Ijtihad membutuhkan ketajaman nalar dan kejujuran hati.

Pada hakikatnya, nassh al-Qur'an maupun hadist Rasulullah S.A.W tidak ada perintah atau anjuran yang secara eksplisit dan teks tual mengacu pekada pencatatan perkawinan. Akan tetapi, terdapat beberapa nash yang secara gamblang menjelaskan pentingnya i'lan (pemberitahuan) peristiwa perkawinan kepada masyarakat. Tidak hanya itu, terdapat beberapa nash hadist juga yang secara tegas memerintahkan pencatatan akad dalam suatu pernikahan.

Abu Zahra menyebutkan bahwa semua ulama fikih setuju dan sependapat bahwa tujuan akhir dari pentingnya saksi nikah adalah pengumuman (إعلان) kepada masyarakat tentang adanya pernikahan. Tujuan orientasi pencatatan tersebut adalah untuk membedakan dan memilah antara pernikahan yang halal dengan yang tidak. Adapun dasar penetapan tersebut adalah sabda Nabi, dan athar Abu Bakar alSiddîq. Menurut Zahrah, apakah dengan dua saksi sudah cukup mewakili pemberitahuan pengumuman, yang berarti tidak perlu adanya penyebarluasan pengumuman secara khusus, bahkan bagaimana kalau persaksian tersebut diperintahkan untuk dirahasiakan. 
Syaltût menerangkan tujuan pencatatan perkawinan adalah untuk memelihara hak-hak dan kewajiban para pihak dalam pernikahan, yakni hak-hak pihak suami dan isteri serta anak-anak keturunannya, seperti pemeliharaan dan warisan. Pencatatan ini sebagai usaha mengantisipasi semakin menipis nya iman seorang muslim. Salah satu bukti akibat menipisnya iman seorang muslim menurut Syaltût adalah semakin banyak terjadi pengingkaranpengingkaran janji yang mengakibatkan dalih untuk lari dari kewajiban. Karena ukuran iman itu adalah sesuatu yang tersembunyi (abstrak), salah satu jalan keluar sebagai usaha preventif agar orang tidak lari dari tanggung jawab, adalah dengan membuat bukti tertulis.

Lebih lanjut, Quraish menjelaskan bahwa semua ulama sepakat tentang larangan merahasiakan pernikahan, hal ini didasari oleh perintah Nabi untuk menyebarluaskan berita perkawinan. Adapun pernikahan dibawah tangan (tanpa pencatatan), dalam konteks Indonesia, menurut Quraish dapat mengakibatkan dosa bagi pelakunya, karena melanggar ketentuan yang di tetap kan oleh pemerintah dan DPR (أولى الأمر). Sedang al-Qur'an memerintahkan untuk mematuhi (taat) kepada pemerintah (أولى الأمر) selama tidak bertentangan dengan hukum-hukum Allah SWT. Sementara perintah pencatatan registrasi pernikahan dan pendataannya sejalan dengan semangat al-Quran. Adapun Nash Qur'an yang secara tegas memerintahkan agar senantiasa taat/patuh kepada Allah SWT, rasul serta pemerintah (uliil amr) sebagaimana yang dikatakan oleh Quraish Sihab adalah dalam surah an-Nisa' ayat ke 59:

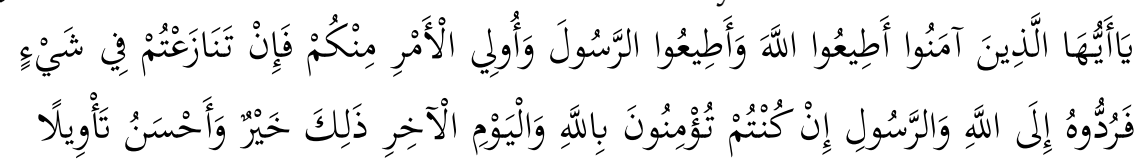

"Hai orang -orang yang beriman, taatilah Allah dan taatilah Rasul (Nya), dan ulil amri di antara kamu. Kemudian jika kamu berlainan Pendapat tentang sesuatu, Maka kembalikan lah ia kepada Allah (Al-Quran) dan Rasul (sunnah-Nya), jika kamu benar-benar beriman kepada Allah dan hari kemudian. Yang demikian itu lebih utama (bagi mu) dan lebih baik akibat nya."

Dengan demikian Nash al-Qur'an dan haditst serta pendapat ula ma memberikan kesimpulan bahwa pencatatan perkawinan 
Imam Hanafi

secara umum dapat dikukan dengan menekankan dan mengutamakan kepada adanya saksi dalam akad pernikahan. Lebih dari itu, para pemikir kontemporer menekankan pada fungsi dan tujuan pencatatan pernikahan sebagai suatu sarana pengumuman serta sebagai butki terjadi nya transak si akad nikah. Sebagai sebuah transaksi, akad nikah tentu melahirkan akibat-akibat hukum di antara para pihak maupun keturunan yang lahir dari perkawinan kelak. Dengan demikian tujuan dan fungsi saksi dalam hal ini adalah untuk menjamin hak dan tanggung jawab pihak-pihak dalam perkawinan. Fungsi dan tujuan inilah yang di-konteks-kan oleh pemikir kontemporer dalam bentuk pencatatan (akte pernikahan), tidak cukup hanya saksi oral, seperti tuntutan pada masa nabi Muhammad SAW dimana masyarakatnya masih masyarakat komunal dan jum lahnya masih relatif sedikit.

\section{Ketentuan Administrasi Pernikahan dalam Perspektif Normatif Undang-Undang Nomor 1 Tahun 1974}

Pernikahan adalah syariat yang diturunkan oleh Allah SWT kepada ummah manusia untuk menjaga salah satu maqasid alsyariah yaitu hifdzun Nasab. Pernikahan merupakan bentuk peekembangan adab manusia dari adab yang jahil kepada adab yang penuh dengan nur. Pada hakikatnya, perkawinan merupakan kebu tuhan dasar manusia yang harus dipenuhi karena menyang kut eksistensi manusia untuk melanjutkan garis keturunannya. Kebebasan untuk menentukan pasa ngan hidup berada di ta ngan manusia seutuhnya. Negara tidak berhak melakukan intervensi soal urusan perkawinan sebagai mana yang dilakukan ayah terhadap anak gadisnya.

Pada hakikatnya, ketentuan yang mengatur persoalan pencatatan perkawinan yang ditetapkan negara bukanlah usaha negara untuk mengintervensi ruang-ruang privat warganya, akan tetapi dijadikan sebagai suatu upaya untuk mengatur administrasi perkawianan warga negaranya, demi kepentingan dan kemaslahatan bersama. Kepastian hukum menjadi salah satu tujuan penting diadakannya aturan tentang pencatatan perkawinan. Adanya pencatatan perkawinan akan menjamin hak masing-masing warga negara dapat terpenuhi. 
Pencatatan pernikahan sama halnya dengan pencatatan dan pendataan peristiwa hukum lainnya, seperti kelahiran dan kematian yang dinya takan dalam daftar pendataan yang telah disediakan. Di negara Indonesia, ketentuan tentang pencatatan perkawinan tertuang dalam UU No.1 Tahun 1974 Pasal 2 ayat (1) dan ayat (2) yang berbunyi:

"Pernikahan adalah sah apa bila dilakukan menurut hukum masing masing agamanya dan kepercayaan itu. Tiap-tiap pernikahan dicatat menurut peraturan perundang-undangan yang berlaku".

Bunyi UU Perkawinan pada butir pasal 2 tersebut ternyata menimbulkan polemik di kalangan para ilmuwan: apakah pencataan perkawinan menentukan sah atau tidaknya suatu perkawinan? Terkait dengan hal ini, ada dua pendapat sarjana hukum sebagaimana berikut ini:

Pertama, Pendapat atas konsep ini cenderung ingin memisahkan penafsiran Pasal 2 ayat (1) dengan aya $t$ (2), bahwa perkawinan adalah sah apabila dilakukan menurut hukum masingmasing agama dan kepercayaan itu, sedangkan pendaftaran adalah syarat administratif saja. Apabila tidak dilakukannya pencatatan perkawinan maka tidak akan mengakibatkan cacat atau tidak sahnya suatu perkawinan.

Kedua, Pendapat ini menafsir kan Pasal 2 ayat (1) dan ayat (2) tidak hanya dilihat dari sudut aspek yuridis saja, yakni terkait sahnya suatu perkawinan, tetapi juga dikait kan dengan aspek sosiologis. Oleh karena itu, Pasal tersebut diatas tidak dapat dipisahkan, karena keduanya saling terkait. Dua ayat tersebut diibaratkan seperti rajutan yang saling jalin menjalin, yang jika salah satu jalinannya lepas maka akan berkurang kekuatan rajutan tersebut dan bahkan akan hilang sama sekali. Sebab, sebuah pernikahan pada hakikatnya akan melahirkan akibat hukum yang melekat pada suami dan istri. Oleh karena itu, mencatatkan pernikahan merupakan sesuatu yang mesti dilakukan demi terwujudnya kemaslahatan dan kepastian hukum. Dicatatkannya sebuah perkawinan akan membantu menjaga masingmasing pihak mendapatkan haknya, dan sekaligus menjadi bukti otentik jika ada perselisihan atau pun wanprestasi.

Selain itu, akta perkawinan juga merupakan salah satu alat bukti yang sah. Dengan demikian dapat dikatakan bahwa keberadaan akta pernikahan secara hukum memegang peranan yang sangat 
penting, khususnya dalam upaya mempertahankan dan melindungi serta mempertahankan hak-hak seseorang dalam membuktikan bahwa suatu peristiwa hukum telah dilakukan. Oleh karena itu, ketika terjadi tuntutan atau gugatan dari pihak lain tentang keabsahan suatu per buatan hukum maka peran alat bukti (dalam hal ini adalah akta perkawinan) menjadi sangat penting. Lahirnya UU. Nomor 1 tahun 1974 memiliki alasan tersendiri. Undang-undang ini merupakan respons dari masalah sosial yang terjadi di masyarakat. Banyaknya praktek pernikahan di bawah tangan (pernikahan yang tidak tercatat) dan atau pernikahan siri ternyata menimbulkan perma salahan yang masih di masyarakat. Banyak perempuan dan anakanak yang menjadi korban dari perkawinan sirri tersebut karena tidak memiliki bukti otentik pernikahan atau surat nikah.

Akan tetapi sayangnya, aturan tentang keharusan mela kukan pencatatan perkawinan tidak disertai dengan sanksi yang bisa membuat pihak yang melanggar peraturan itu menjadi jera. Jika merujuk pada peraturan perundang-undangan sebagai pelaksanaan tata cara perkawinan, yaitu PP Nomor. 9 Tahun 1975, khususnya Pasal 45, disebutkan bahwa hukuman bagi pelanggaran pencatatan perkawinan hanya dikenai denda setinggi-tingginya 7.500 (tujuh ribu lima ratus rupiah). Di sini tampak jelas bahwa negara tidak tegas dengan aturan yang ada. Penjelasan tersebut juga menunjukkan pelanggaran terhadap pencatatan perkawinan tidak mengakibetkan tidak sahnya perkawinan, tetapi hanya dikenakan hukuman..

\section{Administrasi Perkawinan: Kerangka Teoritis Memahami Persyaratan dalam Perkawinan.}

Setiap orang yang akan melangsung kan perkawinan terlebih dahulu harus memberitahukan kepada Pegawai Pencatat Nikah setempat. Pemberitahuan tersebut di lakukan sekurang-kurangnya 10 (sepuluh) hari kerja sebelum perkawinan dilangsungkan. Pengecualian terhadap jangka waktu tersebut diberikan hanya karena suatu alasan yang dianggap sangat signifikan, dan disampaikan kepada Camat atas nama Bupati kepala Daerah.

Pemberitahuan dapat dilakukan secara lisan atau tertulis oleh calon pengantin atau oleh orang tua (wali) calon. Pemberitahuan dimaksud memuat nama, umur, kepercayaan/agama, pekerjaan dan atau profesi, dan tempat tinggal calon pengantin. Apabila salah 
seorang atau kedua nya pernah menikah, maka disebutkan juga nama istri atau suami ter dahulu (Pasal 3, 4 dan 5 PP. 9 tahun 1975), surat persetujuan dan keterangan asal-usul.

Pegawai Pencatat Nikah yang menerima pemberitahuan keinginan hendak nikah tersebut lalu memeriksa calon suami, calon istri, dan wali nikah tentang ada atau tidaknya halangan itu jika pernikahan dilangsungkan. Halangan yang dimaksud, baik halangan berupa pelanggaran hukum munakahat atau pelanggaran peraturan tentang perkawinan.

Sebagaimana penjelasan sebelumnya, maka dengan ini ditegaskan pula dalam pasal 3 ayat (1) Peraturan Menteri Agama Nomor 3 tahun 1975, tentang kewajiban Pegawai Pencatat Nikah dan tata kerja Pengadilan Agama dalam melaksanakan Peraturan Perundang-undangan Perkawinan bagi yang beragama Islam atau disingkat PMA No. 3/1975, yang berbunyi sebagai berikut.

Satu, Seseorang yang hendak menikah, talak/cerai dan rujuk harus membawa surat keterangan dari kepala desa masing-masing menurut contoh model Na-Tra. Dua, Orang yang tidak mempu harus pula membawa "surat keterangan tidak mampu" dari kepala desanya.

Setelah memenuhi tata cara dan syarat-syarat pemberitahuan dan pemberitaan serta tidak ditemukannya sesuatu halangan perkawinan, lalu pegawai pencatat nikah menyampaikan pengumuman berisi pemberitahuan menurut lembar isian formulir yang ditetapkan oleh kantor perwakilan (lampiran XIV).

Pengumuman itu ditandatangani oleh pegawai pencatat nikah dengan menggunakan blangko form model Nc (lampiran XIV) dan memuat: nama, umur, kepercayaan/agama, pekerjaan dan profesi, tempat tinggal dari calon pengantin dan dari orang tua calon mempelai, apabila salah seorang mempelai atau keduanya pernah menikah wajib menyebutkan nama istri dan atau suami mereka terdahulu. Dua, Hari, tanggal, jam dan tempat kedudukan pernikahan akan diselenggarakankan.

Selanjutnya, sejak surat pengumuman keluar dan ditempelkan selama sepuluh (10) hari maka pengumuman tersebut, tidak boleh diambil atau dirobek (pasal 8 dan 9 PP 9/ 75 jo. Pasal 10 PMA 3 /75). Berkaitan dengan hal pemeriksaan perlu kiranya disini dijelaskan terlebih dahulu seluk beluknya. Pemeriksaan berarti, (1) proses, cara, 
perbuatan aktivitas memeriksa; (2) hasil (penghasilan) memeriksa; (3) penyelidikan, pengusutan (perkara dan sebagainya). Jadi, pemeriksaan dilakukan dengan menyelidiki secara teliti hal-ihkwal mengenai pasangan calon suami istri sebelum mereka melangsungkan akad nikah. Hal itu dimaksudkan agar jangan sampai terjadi pelanggaran UU atau hukum yang berlaku, baik hukum Islam maupun hukum negara.

Pemeriksaan tersebut bertujuan untuk mengatisipasi adanyakemungkinan pelanggaran syarat-syarat perkawinan, yang dapat mengakibatkan terjadinya halangan bagi kedua pasangan dalam melangsungkan perkawinan. Ini sesuai dengan Peratu ran Menteri Agama RI Nemor 2 tahun 1990 yang disebutkan dalam pasal 16 yaitu:

Pertama, Setelah diadakan pemeriksaan dan ternyata tidak memenuhi syarat-syarat yang telah ditentukan, maka Pegawai Pencatat Nikah (PPN) atau pembantu PPN wajib menolak berlangsungnya pernikahan tersebut, dengan memberikan surat penolakan kepada orang yang bersangkutan serta alasan penolakannya.

Kedua, Terhadap penolakan sebagaimana dimaksud ayat (1) yang bersangkutan dapat mengajukan keberatan kepada pengadilan yang mewilayahi tempat tinggalnya.

Ketiga, PPN atau pembantu PPN diharuskan melangsungkan pernikahan sebagaimana dimaksud ayat (1) apabila pengadilan memerintahkan pelaksanaannya.

Persyaratan tersebut hanya sekedar sebagai penekanan terhadap syarat-syarat dan prosedur perkawinan yang perlu mendapat perhatian. Jika dalam kenyataannya terdapat persyaratan yang belum dipenuhi, maka pelaksanaan perkawinan yang diajukan dapat ditolak atau ditunda sampai persyaratan dimaksud dipenuhi.

Prosedur dan persyaratan yang demikian birokratis inilah justru akhirnya dapat memunculkan asumsi phobia (takut) dikalangan masyarakat muslim Madura, terutama masyarakat di kecamatan Pakong. Dampaknya kemudian masyarakat yang berkehendak atau berniat melakukan Pencatatan Nikah, enggan karena mendapatkan suatu kesulitan tersebut, di samping memang karena rendahnya kesadaran hukum, dan juga rendahnya pendidikan, sehingga partisipasi masyarakat menjadi sangat minim. 


\section{Bentuk Pelaksanaan Perkawinan}

Aktualisasi pernikahan masyarakat di Kecamatan Pakong Kabupaten Pamekasan secara umum ada dua:

Pertama, perkawinan yang tidak didaftarkan ke KUA (Kantor Urusan Agama). Bentuk perkawinan seperti ini sering terja di kalangan orang-orang yang mengerti hukum agama dan umumnya dilakukan oleh keluarga kiai dan orang-orang terpandang, dalam bentuk perkawinan endogami. Perkawinan endogami ini lebih disukai oleh kalangan kekerabatan yang seketurunan. Masyarakat lebih menyukai mertua yang sekerabat daripada yang tidak ada hubungan kerabat, karena pertimbangannya akan lebih kecil konflik kepentingannya yang muncul.

Dengan demikian, perkawinan semacam ini tidak perlu membutuhkan legal formal dari KUA, karena tujuan utamanya adalah menyambung tali kekerabatan supaya tidak hilang, sehingga mereka sering mengabaikan segi administratif. Mengenai sah tidaknya tergantung pada syarat dan rukunnya nikah, karena perkawinan ini tidak melibatkan pihak-pihak yang lebih luas, sehingga tidak diketahui secara terang-terangan bagaimana motif perkawinannya, dan apa syarat-syaratnya, telah memenuhi prosedur UU yang ada atau belum?

Kedua, perkawinan yang didaftarkan ke KUA (Kantor Urusan Agama) hanya dilakukan bagi kalangan orang-orang yang mampu. Masyarakat yang melangsungkan perkawinan dengan mendaftarkan diri ke KUA hanya orang-orang yang didukung oleh biaya memadai, sehingga mereka langsung ke KUA dan mengajukan permohonan untuk dilangsungkan akad nikah.

Umumnya masyarakat lebih mengutamakan upacara akad nikahnya, baru berselang kemudian, mendaftarkan diri ke Kantor Urusan Agama, kemudian dilangsungkan acara resepsi walimatul 'ursy sebagai salah satu bentuk syukur kepada Allah SWT karena dapat mengamalkan sunnah Rasul yaitu pernikahan. Hal ini dilakukan karena kondisi ekonomi yang memprihatinkan, sehingga mempengaruhi pelaksanaan acara perkawinan. Mereka lebih mementingkan kesederhanaan dalam melaksanakan acara perkawinan. Bagi mereka yang terpenting adalah telah mengikuti ajaran Nabi Muhammad SAW yang berupa nikah itu dengan baik. 
Setelah keadaan ekonomi sudah mapan dan ada keinginan, mereka mengadakan acara selamatan perkawinan secara lebih terbuka (diketahui oleh orang banyak termasuk para famili dan kerabatnya). Pada acara ini biasanya semua tokoh masyarakat di undang termasuk petugas dari KUA juga dimintai untuk hadir. Kehadiran petugas KUA di samping untuk menyaksikan, juga untuk mencatat perkawinannya. Lebih dari itu, juga untuk menyambung tali silaturrahmi guna untuk mempertemukan hubungan pergaulan yang lebih luas lagi, dan ini menjadi kebanggaan tersendiri atas kemampuannya dapat menghadirkan seluruh tokoh penting, utamanya para ulama kyai terkenal.

Ketiga, perkawinan yang didaftarkan ke KUA (Kantor Urusan Agama) bagi kalangan orang-orang yang tidak mampu. Perkawinan seperti ini dilakukan oleh masyarakat yang sudah mengerti terhadap aturan agama dan pemerintah, serta mengetahui bagaimana pentingnya legalitas perkawinan yang dibuktikan dengan "akta nikah" sebagai kekuatan hukum resmi. Biasanya dilakukan oleh masyarakat yang sudah terpelajar dan banyak menerima penyuluhan dari para tokoh masyarakat dan Kyai, aparat desa dan pembantu pegawai pencatat nikah (modin), yang menyelenggarakan perkawinan secara terbuka dan disaksikan oleh masyarakat banyak.

Masyarakat menghendaki agar perkawinan terselenggara sesederhana mungkin, tetapi resmi dan menghendaki pula perolehan tanda bukti akta nikah, sebagai bentuk legalitas. Kelegalitasan tersebut dianggap sebagai satu faktor yang dapat menciptakan ketenangan rumah tangga dikemudian hari, apabila kelak ada perselisihan dan problema.

Ada pun persyaratan administrasi pernikahan dan berkas surat-surat yang diperlukan: Surat kete rangan untuk nikah dari Lurah / kepala desa (Model N.1); Kutipan akte kelahiran / surat keterangan asal usul dari ke pala desa/ kelurahan (N.2); Surat persetujuan kedua calon pengantin (Model N.3); Surat keterangan tentang orang tua dari lurah/kelurahan (N.4); Surat ijin orang tua (N.5)/pengadilan agama bagi calon pengantin yang berumur kurang 21 tahun; Surat keterangan kematian suami/istri (N.6) bagi duda/janda mati; Akta cerai atau kutipan buku pendaftaran talak/cerai bagi mereka yang perceraiannya terjadi sebelum berlakunya UU. No. 7/1989. (sebelum 1 April 1990); Izin Pengadilan 
Agama bagi yang akan berpoligami; Izin dari pejabat yang berwenang bagi anggota TNI / POLRI.

\section{Pelaksanaan Persyaratan Administrasi Perkawinan}

Pelaksanaan perkawinan yang dilakukan oleh masyarakat Kecamatan Pakong Kabupaten Pamekasan, biasanya mendaftar ke perangkat desa dan pembantu pegawai pencatat nikah (modin), dengan memberitahukan kehendak untuk melangsungkan perkawinan.

Proses awal sebelum dilangsungkannya perkawinan, mereka memberitahukan terlebih dahulu kepada tokoh masyarakat, dalam hal ini Kyai, aparat desa dan pembantu pegawai pencatat nikah (modin) dan orang-orang yang membantu dalam melaksanakan akad nikah. Selanjutnya, pelaksanaan perkawinan menunggu hari baik, sampai saat ini dipraktekkan turun temurun dari nenek moyang yang disebut dengan "dinah esak".

Setelah ditentukan tanggal dan harinya, kemudian mereka datang ke KUA untuk mendaftarkan perkawinan. Selanjutnya petugas yang berkompeten melakukan proses pemeriksaan dan penetapan hari melaksanakan perkawinan. Masyarakat yang mendaftarkan perkawinan dalam waktu yang sangat singkat, menyulitkan petugas melakukan pemeriksaan secara mendetail.

Pendaftaran ke KUA biasanya perkawinan yang telah diakad oleh tokoh agama (Kyai), sehingga dalam berkas pendaftaran hanya membutuhkan tanda tangan petugas. Hal ini dilakukan karena didesak oleh suatu kepentingan, dan mereka ingin mendapatkan legalitas perkawinan yang berupa akta nikah. Dengan keadaan demikian, petugas pencatat nikah (PPN) tidak dapat memeriksa dan meneliti secara detail terhadap status dan kondisi pasangan calon suami istri tersebut. Seharusnya masyarakat yang ingin mendaftarkan perkawinannya ke KUA, baik melalui aparat desa dan Modin, dilakukan jauh sebelum pelaksanaan perkawinan dilangsungkan, agar petugas pencatat nikah dapat memeriksa dan meneliti data pasangan kedua calon suami istri dengan baik, dan hal-hal yang dianggap kurang memenuhi syarat segera diketahui dan dapat dimintakan kelengkapannya. 
Selanjutnya, peristiwa perkawinan yang dilakukan masyarakat Pakong selama tahun 2018 dapat dilihat pada data berikut:

\begin{tabular}{|c|l|c|c|c|}
\hline No & \multicolumn{1}{|c|}{ Bulan } & Nikah & BD ( Bedolan ) & KT ( Kantor ) \\
\hline 1 & Januari 2019 & 14 & 38 & 4 \\
\hline 2 & Pebruari 2019 & 30 & 41 & 8 \\
\hline 3 & Maret 2019 & 20 & 7 & 4 \\
\hline 4 & April 2019 & 12 & 9 & 5 \\
\hline 5 & Mei 2019 & 24 & 7 & 4 \\
\hline 6 & Juni 2019 & 16 & 12 & 5 \\
\hline 7 & Juli 2019 & 15 & 26 & 10 \\
\hline 8 & Agustus 2019 & 6 & 36 & 11 \\
\hline 9 & $\begin{array}{l}\text { September } \\
2019\end{array}$ & 60 & 30 & 9 \\
\hline 10 & Oktober 2019 & 43 & 33 & 74 \\
\hline 11 & $\begin{array}{l}\text { Nopember } \\
2019\end{array}$ & 35 & 14 & $\mathbf{7 4}$ \\
\hline 12 & $\begin{array}{l}\text { Desember } \\
2019\end{array}$ & 29 & 32 & \\
\hline
\end{tabular}

Dilihat dari peristiwa perkawinan selama tahun 2018, penulis temukan bahwa yang melaksanakan perkawinan di luar BD (Bedolan). lebih banyak daripada melaksanakan di kantor.

Walaupun pelaksanaan perkawinan yang dilaksanakan melalui kantor lebih sedikit, tetapi seringkali masih kurang optimal. Masyarakat sering hanya mengutamakan pelaksanaan akadnya saja, 
karena dengan dilaksanakannya akad menurutnya sudah dianggap selesai suatu perkawinan. Mereka tidak memikirkan jangka panjangnya, maksudnya bagaimana sesudahnya.

Sebenarnya pelaksanaan perkawinan yang selama ini penulis temukan, baik diperiksa maupun tidak diperiksa oleh petugas saat sebelum dilangsungkan perkawinan, dipandang sebagai hal yang biasa oleh masyarakat. Bagi masyarakat Pakong pelaksanaan perkawinan tidak perlu dan tidak mau menempuh jalan terlalu sulit dan berbelit-belit itu.

Biasanya calon wanita yang kebetulan alumni dari pondok, terlebih dahulu oleh kyainya (masih) diberi nasehat-nasehat serta diadakan acara pelepasan dari lingkungan pondok pesantren di mana ia menimba ilmu. Hal demikian ini sebagai wujud dari bentuk takdim seorang santri kepada kyai sekaligus untuk memperoleh barokah darinya.

Pasangancalon suami atau istriyang dari pondok, oleh kyainya sudah dianggap bisa atau mampu untuk memasuki pintu perkawinan, dan kyai menjamin bahwa mantan santrinya itu telah cukup bekalnya dengan ilmu yang diperoleh dari pesantren, serta tidak perlu dikhawatirkan lagi. Dengan demikian, pemeriksaan pranikah tidak bisa serta merta dilaksanakan secara administratif dengan prosedur birokratis yang panjang. Hal itu disebabkan pihak pondok merasa telah cukup membina dan mengajari hal ihkwal ilmuilmu agama termasuk ilmu bermasyarakat, sehingga kedua pasangan calon suami istri tersebut telah cukup dengan segala sesuatunya, dan selanjutnya diantar ke rumah tempat dilangsungkannya akad nikah.

Demikian pula masyarakat seringkali melaksanakan perkawinan mendadak, dalam arti pendaftaran dan pelaksanaannya sangat mendesak. Hal ini karena adanya suatu kepentingan, sehingga pelaksanaan perkawinannya tidak optimal. Tidak optimal yang dimaksud adalah tidak cukupnya waktu bagi petugas untuk memeriksa persyaratan yang diperlukan. Hal itu disebabkan yang bersangkutan segera meninggalkan kampung halaman misalnya, karena yang bersangkutan akan bepergian jauh keluar negeri untuk mengadu nasib dan mencari pekerjaan. Bahkan, ada juga karena suatu keperluan mendesak lainya, akhirnya mendaftarkan hajat perkawinan kepada petugas, tetapi sesungguhnya mereka telah 
melakukan akad nikah terlebih dahulu, hal yang demikian ini disebut dengan istilah"kawin setor".

Kondisi yang semacam ini tidak memungkinkan terlaksananya pemeriksaan perkawinan secara maksimal. Oleh karena itu, selama pemeriksaan tidak diefektifkan maka pelaksanaan perkawinan tidak dapat diketahui celah-celah kekurangannya, mana yang telah memenuhi syarat secara syar'i/ pemerintah, serta hal-hal yang menjadi halangan perkawinan.

\section{Faktor Penghambat Pelaksanaan Persyaratan Administrasi Perkawinan}

Faktor Sosial

Kehidupan masyarakat desa yang berlatar belakang bertani, sangat berpengaruh terhadap pola pandang dan pemikirannya.Ketika hasil tani tidak mencukupi untuk memenuhi kebutuhan hidupnya, maka masyarakat mencari alternatif untuk mengubah nasib dengan mencoba cari pekerjaan ke luar negeri.

Salah satu persyaratan yang selama ini paling dibutuhkan adalah bukti surat nikah, sehingga mereka datang ke KUA untuk didaftarkan nikahnya hanya karena ingin memperoleh legitimasi saja. Kondisi semacam inilah yang mengakibatkan proses pelaksanaan perkawinan terjadi dengan terburu-buru, danalasan mereka karena akan segera berangkat bekerja ke luar negeri, serta surat nikah tersebut diperlukan untuk mengurus persyaratan memperoleh visa.

Bahkan, karena dorongan yang kuat untuk bekerja di luar negeri, dengan gaji besar dan upah yang menjanjikan, masyarakat awam tidak mengetahui jika surat nikah tersebut sebagai tanda bukti yang mempunyai konsekuensi moral dan tanggungjawab suami istri, melainkan mereka menganggap nilainya tak lebih hanya sebagai salah satu kelengkapan visa untuk dapat lolos sebagai tenaga kerja diluar negeri. Akhirnya, anggapan masyarakat bahwa KUA sebagai lembaga/instansi yang dapat memperjualbelikan surat nikah, seperti halnya KTP, SIM atau surat akta kelahiran. Hal ini diketahui ketika suatu saat ada masyarakat yang datang ke KUA mencoba untuk mendapatkan surat nikah dengan membayar berapa saja asalkan surat nikah didapat.

Faktor Keterbatasan Waktu 
Kehidupan masyarakat tidak terlepas dari pengaruh lingkungan dan keper- cayaan yang merupakan bagian tidak terpisahkan dari keyakinan agamanya. Kepercayaan ini selamanya melekat, walaupun pendidikan sebenarnya masih bisa mempengaruhinya.

Masyarakat muslim Madura di kecamatan Pakong kabupaten Pamekasan, walaupun sebagian besar masyarakatnya berpendidikan, dan pada umumnya mondok, tetapi kehidupan sehari-harinya tetap dipengaruhi oleh keyakinannya. Demikian juga masalah perkawinan, merupakan sesuatu yang tidak pernah lepas dari kehidupannya, baik sebagai kebutuhan pribadi maupun sosial.

Tampaknya di hati masyarakat masih tertanam kuat keyakinan terhadap "sangkal", yaitu apabila ada seorang laki-laki senang terhadap perempuan dan dirasakan cocok, maka pihak perempuan tidak boleh menolaknya dan laki-laki tersebut harus langsung diterima sebagai calon suaminya. Apabila menolak, akan menerima sangkal.

Ketika kedua calon ini akan melangsungkan perkawinan secara resmi, maka proses pemeriksaan seakan-akan tidak diperlukan, karena bagaimanapun dan apapun hasil pemeriksaan itu tetap tidak akan mempengaruhi kedua calon mempelai melangsungkan perkawinan dan menjadi suami istri. Keyakinan semacam inilah yang masih turun temurun, terutama di kalangan para kerabat dalam sistem perkawinan endogami yang mengambil calon jodoh hanya dikalangan kerabat dan sudah dipastikan bahwa tidak ada pihak manapun yang dapat menggagalkan perkawinannya.

Selanjutnya, keyakinan terhadap penentuan hari dan waktu baik, dapat pula menyulitkan petugas pencatat nikah.Misalnya waktu pelaksanaan perkawinan tengah malam 23.00 WIB. Tentunya keadaan semacam ini akad nikahnya hanya dilaksanakan oleh tokoh-tokoh masyarakat saja, sehingga pemeriksaan nikah tidak dapat dan tidak mungkin dilaksanakan.

Hambatan seperti ini tidak lepas dari peranan tokoh-tokoh masyarakat sendiri yang mempengaruhi umatnya didalam melestarikan nilai-nilai keyakinan yang semakin mengakar kuat. Anehnya keadaan yang demikian ini selalu dihubungkan dengan nilai kesakralan perkawinan, bahkan pada nilai-nilai keabsahannya. 
Oleh karena itu, keyakinan masyarakat yang demikian mengakar itu, sulit rasanya untuk dihilangkan karena apabila mereka tidak melestarikan keyakinan tersebut dianggap menyalahi tradisi dan menentang para kaum seppo (tetua adat).

Faktor Adat

Ada pandangan yang berbeda-beda di kalangan masyarakat tentang bagaimana hukum berada ditengah-tengah mereka, dan bagaimana pula memberlakukan hukum tersebut. Sebagian masyarakat ternyata masih belum mendalami tentang hukum-hukum yang menyakut perkawinan, sehingga mereka tidak mampu melaksanakan hukum tersebut secara nyata.

Apalagi masyarakat selama ini hanya memandang hukum agama saja yang mengatur perkawinan, dan juga hanya dipahami serta dilaksanakan secara sepotong-sepotong, menyebabkan mereka kurang begitu peduli dengan keberadaan hukum positif negara. Jika dibandingkan dengan hukum Islam (fiqih munakahat) seakan-akan kurang mendapat perhatian sepenuhnya. Hukum yang tidak dapat dijalankan pada hakikatnya telah berhenti dari fungsinya sebagai hukum .

Pada hakekatnya hukum tidak berfungsi tanpa ada orang yang mau melaksanakannya.Karena itu, bagaimanapun hukum memerlukan campur tangan orang dalam pelaksanaannya. Hukum perkawinan yang memuat aturan-aturan, kadang kala hanya dilaksanakan sesuai dengan situasi dan kondisi atau tergantung kepada kebutuhan masyarakat, yang pada akhirnya nilai-nilai dan kekuatan hukum tersebut semakin hilang.

Realita di masyarakat bahwa, di dalam proses pranikah sampai pada pelaksanaan akadnya, masyarakat tidak memiliki acuan yang mendalam tentang hukum yang dipergunakan. Masih unsur kepentingan yang menyebabkan nilai-nilai hukum terpinggirkan.

Selama ini aturan tentang pemeriksaan pranikah oleh masyarakat dianggap mengada-ada dan justru dicurigai, karena masyarakat menganggap bahwa petugas pencatat nikah ketika datang ke rumah calon, masih kurang percaya terhadap kondisi dan status kedua calon suami istri tersebut.

Petugas dianggap mempersulit keperluan (hajat) dari keluarga calon mempelai, dan karena itu, keluarga mempelai merasa tidak perlu lagi diperiksa oleh petugas. Diperkuat oleh persepsi dan 
kesaksian masyarakat bahwa calon mempelai tidak ada masalah atau tidak memiliki latar belakang buruk, sehingga tidaklah ada masalah yang perlu diperiksa. Bagi masyarakat, yang paling penting adalah bagaimana proses perencanaan hajat perkawinan tersebut dapat lancar sampai pada pelaksanaan perkawinan, atau masyarakat lebih mementingkan aspek sakralnya saja, yakni "akad nikah", yang disertai dengan mengundang tokoh-tokoh masyarakat dan agama setempat.

Faktor Intervensi Kyai

Tidak dapat dipungkiri lagi, bahwa orientasi legitimasi masyarakat pedesaan di Madura pada umumnya ialah kiai, dan bukan pada kepemimpinan birokrasi. Hal ini karena mereka banyak memberikan kontribusi bagi peningkatan dan perkembangan masyarakat.

Eksistensi kiai sesungguhnya telah menjadi pemimpin nonformal bagi masyarakat di sekitarya. Dalam konteks kebangsaan dan kenegaraan, peran dan fungsi kiai itu, melengkapi kelebihan dan kekurangan yang terdapat pada jajaran pemerintahan mulai desa sampai tingkat daerah. Karenanya, tak heran para pejabat desa, kecamatan, kabupaten dan propinsi memerlukan diri untuk meminta nasehat kepada kyai.

Sebenarnya kyai adalah orang yang biasa saja. Hanya saja orang tersebut diakui keberadaanya memliki kelebihan dan kistimewaan (maziiyatun), daripada orang kebanyakan. Di kalangan masyarakat desa, kiai dianggap memeliki kekuatan spiritual untuk menjawab berbagai problema yang timbul. Masyarakat seringkali mengungkapkan segala kegundahan permasalahan dan problema hidup, termasuk yang menyangkut masalah perkawinan kepada sosok kyai, dan seorang kyai di desa dengan ketulusan hatinya melayani kepentingan masyarakat tersebut dengan penuh kesabaran, baik masalah yang menyangkut hajat hidup mereka berdasarkan nilai dan ajaran-ajran agama maupun hal-hal lain yang menyangkut sosial kemasyarakatan.

Demikian pula ketika masyarakat hendak mengadakan hajat untuk menikahkan putranya, ia datang ke kyai untuk minta petunjuk dan arahan-arahan. Termasuk dalam menentukan tanggal dan hari baik, sampai pelaksanaan akad nikah semuanya dipasrahkan penuh kepadanya. 
Mengingat masyarakat kecamatan Pakong hatinya masih tertanam sikap dan rasa tawadu' yang kuat terhadap keberadaan kyai, sehingga setiap keperluan masyarakat, kiailah sebagai figur yang menyelesaikan segala persoalan. Bahkan, termasuk urusan yang menyangkut birokrasi pemerintah, kyailah sebagai penentu kebijakan walaupun dengan bahasa awam, masyarakat datang ke beliau untuk "minta restu" agar apa yang menjadi kehendak dikabulkan.

Oleh karena itu, dalam pelaksanaan proses pernikahan sampai kepada prosesi akad nikah, masyarakat masih mempercayakan kepada sang kyai. Berdasarkan keyakinan mereka bahwa kyai adalah orang yang lebih dekat kepada Allah, termasuk doanya langsung mustajab. Apalagi masyarakat masih menilai sosok kyai adalah orang yang perbuatannya selalu benar dan tidak pernah salah.

Inilah sebuah kultur masyarakat muslim Madura di kecamatan Pakong kabupaten Pamekasan yang masih kental dengan figur kyai sebagai tokoh panutan, sehingga dalam segala hal mereka beradu kepada kyai, termasuk urusan perkawinan, semua diserahkan kepada sang kyai.

\section{Penutup}

Setiap orang yang akan melaksanakan pernikahan terlebih dahulu harus memberitahukan kepada Pegawai Pencatat Nikah setempat. Pemberitahuan tersebut dilakukan sekurang-kurangnya 10 (sepuluh) hari kerja sebelum pernikahan. Pelaksanaan perkawinan masyarakat di Kecamatan Pakong Kabupaten Pamekasan secara umum dilakukan dengan beberapa prosedur, antara lain:

Pertama, Perkawinan yang tidak didaftarkan ke KUA (Kantor Urusan Agama).

Kedua, Perkawinan yang didaftarkan ke KUA (Kantor Uruusan Agama) hanya dilakukan bagi kalangan orang-orang yang mampu.

Ketiga, Perkawinan yang didaftarkan ke KUA (Kantor Urusan Agama) bagi kalangan orang-orang yang tidak mampu.

\section{Daftar Pustaka}

Badan Kesejahteraan Masjid (BKM) Pusat, Pedoman Pegawai Pencatat Nikah, Jakarta: 1992/1993. 
Darajat, Zakiah, Perkawinan yang Bertanggung Jawab, Jakarta: Bulan Bintang, 1975.

Departemen Agama RI, Undang-undang No. 1 Tahun 1974 dan Peraturan Pemerintah No. 9 Tahun 1975, Jakarta: 2003.

Departemen Pendidikan dan Kebudayaan, Kamus Besar Bahasa Indonesia, Jakarta: Balai Pustaka, 1990.

Djamil, Fathurrahman, Filsafat Hukum Islam, Jakarta: Logos Wacana Ilmu, 1999.

Kuntowijoyo, Radikalisasi Petani, Yogyakarta: Bentang Budaya, 2002

Mas'ud, Abdurrahman, Intelektual Pesantren, Yogyakarta: LKiS, 2004.

Nasution, Khoiruddin, Islam Tentang Relasi Suami Istri, Yogyakarta: Tazzafa dan Akademia, 2004.

Peraturan Menteri Agama RI Nomor 2 tahun 1990, Pasal 16 Ayat 1,2,3.

Praja, Juhaya S., Filsafat Hukum Islam. Bandung: LPPM Universitas Islam Bandung, 1995.

Raharjo, Sucipto, Hukum dan Masyarakat, Bandung: Angkasa, 1986.

Ramulyo, Moh. Idris, Hukum Perkawinan Islam, Jakarta: PT. Bumi Aksara, 2002

Toha, Zainal Arifin, Runtuhnya Singgasana Kiai, Yogyakarta: Kutub, 2003. 